\title{
ALCOHOL CONSUMPTION BY NURSING STUDENTS IN HONDURAS
}

\author{
Rosa Camila Matute ${ }^{1}$
}

Sandra Cristina Pillon ${ }^{2}$

Matute RC, Pillon SC. Alcohol consumption by nursing students in Honduras. Rev Latino-am Enfermagem 2008 maio-junho; 16(especial):584-9

The recreational use of alcohol is very frequent in the life of college students. A descriptive study was carried out with nursing students in Honduras, where the use of psychoactive substances represents a considerable health problem, especially the use of alcohol. This study identified that $74.9 \%$ were abstinent. Nevertheless, the study focused on drinkers, whose consumption pattern may be changing over time. According to the sample characteristics, most subjects were young working women, students, and Christians. These variables should be considered in the investigation of protective factors against drinking, and in designing preventive actions in the university context.

DESCRIPTORS: alcoholism / prevention \& control; student, nursing

\section{USO DE BEBIDAS ALCOHÓLICAS ENTRE ESTUDIANTES DE ENFERMERÍA EN HONDURAS}

El uso recreativo de alcohol esta muy presente en la vida de los universitarios. Por medio de un estudio descriptivo entre estudiantes de enfermería en Honduras se encontró que el uso de sustancias psicoactivas producen un gran daño a la salud, principalmente el uso de alcohol. En el presente estudio, se identificó que el 74.9\% era abstemio, pero nuestra atención se volvió hacia los bebedores, porque estos a lo largo del tiempo pueden estar cambiando su patrón de consumo. En la caracterización de la muestra, se encontró que la mayoría eran jóvenes, evangélicas, que estudian y trabajan. Esos son variables de consideración para una mejor exploración de los factores de protección de bebedores y el planteamiento de acciones preventivas en el contexto universitario.

DESCRIPTORES: alcoholismo / prevención y controle; estudiante de enfermería

\section{USO DE BEBIDAS ALCOÓLICAS EM ESTUDANTES DE ENFERMAGEM EM HONDURAS}

O consumo de álcool, de forma recreacional, está muito presente na vida dos universitários. Através de estudo descritivo com estudantes de enfermagem em Honduras, foi descoberto que o uso de substâncias psicoativas representa um grande problema para a saúde, principalmente o uso do álcool. Identificamos, no presente estudo, que $74,9 \%$ eram abstinentes, porém, a nossa atenção se voltou aos consumidores, pois estes ao longo do tempo podem estar mudando seu padrão de consumo. Na caracterização da amostra, a maioria são mulheres, jovens, evangélicas que estudam e trabalham. Estas são variáveis a considerar para melhor exploração dos fatores de proteção do beber e planejamento de ações preventivas no contexto universitário.

DESCRITORES: alcoolismo / prevenção \& controle; estudantes de enfermagem

\footnotetext{
${ }^{1}$ Specialist in Perinatal Health, Teaching Diploma, Faculty, National Autonomous University of Honduras; ${ }^{2}$ PhD, Faculty, University de São Paulo at Ribeirão Preto, College of Nursing, WHO Collaborating Centre for Nursing Research Development, Brazil e-mail: pillon@eerp.usp.br
} 


\section{INTRODUCTION}

The consumption of and dependence on substances constitutes a significant burden for individuals and societies all over the world. The 2002 World Health Report ${ }^{(1)}$ indicated that $8.9 \%$ of total morbidity is due to the consumption of psychoactive substances. The use of alcohol is particularly problematic in Latin American and Caribbean countries. While the proportion of dysfunctions or deaths in the world which can be related to the use of alcohol is around $1.5 \%$, this number reaches $4.5 \%$ in those countries ${ }^{(2)}$.

In developing countries like Honduras, the level of psychoactive substance abuse is one of the problems that most affect health. The substances likely to develop problems and dependence include alcohol and tobacco, which are considered the legal drugs with the highest consumption levels in different population groups ${ }^{(3)}$.

Honduras is a country located in the middle of the Central American isthmus. Its geography has contributed to economic and social fragmentation, and it was considered a drug traffic route in the $80 \mathrm{~s}$. However, in the 1990's, it also became a consumer. The consumption of certain types of substances is part of the cultural context of different Honduran communities ${ }^{(4)}$.

The consumption of alcohol is one of the main Public Health problems and considerably affects the most vulnerable sectors of society, such as young people, particularly students, who are in a stage of life when the risk of initiating the consumption of alcohol and tobacco is the highest. These are considered the entry door for the use of other drugs.

In a review about the consumption of drugs in Honduras, the author ${ }^{(5)}$ refers that, so far, there were no national studies, but only partial investigations in some communities that are considered risk populations, mainly looking at high school students. The results show considerable rates in public sectors, such as students in high schools and normal schools (which qualify teachers), street children, and marginal colonies located in the metropolitan area of the main cities in Honduras.

The most recent studies have showed no differences in this panorama, as appointed by the Honduran Institute for the Prevention of Alcoholism,
Drug Addiction and Drug Dependence, responsible for the policies of preventing legal and illegal drugs in the country. It indicates a prevalence of $40.7 \%$ for the consumption of alcohol in high school students between 15 and 17 years old ${ }^{(3)}$.

Studies of college students carried out in Latin countries show consumption rates of alcoholic beverages exceeding 50\%. Therefore, this group presents a behavior pattern of consuming alcoholic beverages which differs from the general population ${ }^{(6)}$, and is also in a vulnerable position for consumption and involvement in risky behavior, which is one of the biggest health concerns ${ }^{(7)}$.

A study carried out with a sample of 210 nursing students in Bolivia, with the purpose of evaluating drugs use and related attitudes, revealed that $33 \%$ had ingested alcohol in the last year and approved its ingestion ${ }^{(8)}$.

An AUDIT validity study with 302 university students in Mexico showed that 40 (13\%) abstained from drinking, 88 (29\%) were high-risk drinkers, and $103(34 \%)$ fit the dependence criteria ${ }^{(9)}$. These studies are not very different from those carried out with Colombian university students ${ }^{(10)}$ in which $60(13.3 \%)$ abstained from drinking, 225 (50\%) consumed moderately, $27.8 \%$ (125) showed abusive consumption and $40(8.9 \%)$ were dependent. Although the drinking classification may vary, the number of consumers was rated as considerably disquieting.

A Chilean study about how much and when university students drink ${ }^{(11)}$ showed a pattern of alcohol consumption associated with risk in the population. Among 528 students, they found that $82 \%$ of the men and $79 \%$ of the women consumed alcoholic beverages, mainly with high alcohol levels. Occasional consumption happens during parties and celebrations, but $30 \%$ of the men and $15 \%$ of the women got drunk in the last year. Problem drinking is present in $9 \%$ of the men and $3 \%$ of the women. Finally, students who stop drinking alcoholic beverages are only able to do it for short periods of time.

Studies carried out in Ecuador ${ }^{(12)}$ and in Brazil (13) show that alcohol is one of the main recreational drugs in the college community ${ }^{(12-13)}$. The AUDIT study on the use of alcohol among 254 nursing students in a public school in Brazil identified that the level of alcohol consumption was above expected 
limits: $63 \%$ presented basic risk use, $18.5 \%$ low risk use and $2 \%$ harmful use. These levels are considered risky to control the problem and preventive interventions are needed in the average university student public, mainly because this sample was composed of women ${ }^{(7)}$.

A literature review revealed no studies in Honduras regarding average consumption of alcohol, tobacco and other types of drugs among nursing students, which justifies the development of this study even more.

\section{TEST FOR ALCOHOL USE IDENTIFICATION (AUDIT)}

This test was carried out to detect the harmful use of alcohol in early phases among adults in primary care $^{(14)}$. Nowadays, it is a very useful tracking instrument in populations receiving clinical care, and also for groups considered at risk, in order to examine drinking problems in students, for example. One of the proposals of the World Health Organization is to utilize the AUDIT in several regions of the world with different drinking styles(14), so as to allow for a comparison among different cultures.

The test contains ten questions to evaluatethree ratings, which are: level of alcoholic beverage consumption (three questions), signals and symptoms of dependence (three questions) and consequences related to drinking (four questions). In order to read the levels of consumption, answers have to be added up, with a range from 0 to 40 points, with (0) equaling abstinence, ( 1 to 7 points) low risk use, ( 8 to 15 points) risky use, (16 to 19 points) harmful use and (20 or more points) probable dependence. There is no alcohol consumption without risks, so if the user were evaluated as a non-drinker or drinker, it would result in an all-or-nothing situation. The AUDIT is an instrument to help knowing and distinguishing the different levels of consumption, as well as the use, abuse (harmful use) and dependence of alcohol $^{(14)}$. Thus, everybody is classified in the same way, i.e. dependents and non-dependents, so different levels of care can be offered to different kinds of users. As far as definitions go, it can be said that "use" refers to any ingestion of alcohol. The "low risk use of alcohol" means that the individual does not have problems as a consequence of alcohol use. And "abuse of alcohol" is a general term used for any level of risk, that is, a social, psychological or physical problem that may develop. Even so, the development of dependence may be underway. It is important to emphasize that low risk use corresponds to the consumption of two doses by women (two bottles of beer) and up to three for men (three bottles of beer $)^{(14)}$, and that each of the doses is equivalent to 10-12 grams of pure ethanol. Higher consumption levels on one single occasion are considered abuse.

The present study aims to assess the average consumption of alcohol among nursing students.

\section{METHODOLOGY}

This is a descriptive study, part of the CICAD/ OEA Project. Participants come from Latin American and Caribbean countries, working together to educate nurses in the studies about drugs, with the purpose of reducing demand in those regions. The present study was carried out by the Medical Sciences College at the Autonomous National University of Honduras (UNAH.FCM), through the department of Nursing, where 795 nursing students were enrolled in 2005. The sample was composed of 191 students (24\%). A structured questionnaire was used to collect the data, with objective answers about te sociodemographic information, as well as the AUDIT, with ten questions that identify the use of alcohol in the past 12 months. During data collection, the students were instructed about the research, having all kinds of questions answered and having the anonymity of their questionnaires guaranteed. The study was approved by the review board of the FCM.UNAH, A database was designed in SPSS (Statistical Package for Social Sciences v.11) software to process the data. Data analysis is presented in frequencies and percentages.

\section{RESULTS}

The questionnaires were distributed to the students present in the classrooms, totaling 191 (100\%) nursing students in 2005 who were taking the first and fourth course years. These data were taken from a population of $795(100 \%)$ enrolled students. 
Sociodemographic characteristics

Table 1 - Distribution of sociodemographic characteristics of nursing students at FCM.UNAH $(n=191)$

\begin{tabular}{lcc}
\hline Age & N & \\
Average 23.65 years old & & \\
Sd 6.29 & & \\
Min-Max 17-49 years old & 91 & 48 \\
\hline Religion & 81 & 42 \\
$\quad$ Evangelic & 4 & 2.1 \\
$\quad$ Catholic & 5 & 2.6 \\
Mormon & 8 & 4.2 \\
Other & & \\
$\quad$ None & 108 & 56.5 \\
Working & 82 & 42.9 \\
Yes & & \\
$\quad$ No & 183 & 95.8 \\
Gender & 8 & 4.2 \\
Female & & \\
Male & 113 & 59.2 \\
Marital Status & 72 & 37.7 \\
Single & 6.1 \\
Married/living with partner & & \\
No answer & 54 & 28 \\
School year & & \\
4th year & & \\
1st year & & \\
\hline
\end{tabular}

Regarding gender, the profession is composed by young people, mostly women (95.8\%), which is similar to data on the nursing career in other countries. Furthermore, $113(59.2 \%)$ are single and nearly half (56.5\%) work in areas related to nursing.

Regarding religion, 91 of the students (48\%) are evangelic and 81 (42\%) catholic.

Class Schedule: $76(40 \%)$ of the students are enrolled in the morning period and 69 (35\%) have a mixed schedule (afternoon and evening). Regarding how frequently they attend classes, 124 (65\%) are never absent. An evaluation of the academic performance was then performed, considering only the average grade in the first semester: 158 (83\%) had grades between 60 and $79 \%$, which in the evaluation system is equivalent to acceptable or good. Regarding social relationships with classmates, 170 $(89 \%)$ consider that they have a friendly relationship.

Alcohol Consumption by Nursing Students

The investigation of the risk levels of alcohol use in nursing students who drink showed that the majority (74.9\%) are abstinent, with 143 students, while $48(25.1 \%)$ consume alcoholic beverages, as shown in the table below.
Table 2 - Distribution of Alcohol Consumption Pattern among nursing students

\begin{tabular}{lcc}
\hline $\begin{array}{c}\text { Alcohol consumption } \\
\text { level }(\mathbf{n = 1 9 1 )}\end{array}$ & $\mathbf{N}$ & $\%$ \\
\hline Abstinent & 143 & 74.9 \\
Low risk & 42 & 22.0 \\
Risky & 6 & 3.1 \\
\hline
\end{tabular}

Of the $48(100 \%)$ students who drink, 42 $(87.5 \%)$ present low risk consumption (drinking once a month, one or two doses), and six (12.5\%) present risky behavior (drinking more than three doses). Getting drunk is present among 12 (25\%) students.

When asked about participation in parties, 107 $(56 \%)$ said they had participated in parties in the last year, 56 (29\%) of whom said they had consumed alcoholic drinks during the parties. Next, the frequency at which the students attend these parties was evaluated, and $16(15 \%)$ were found to participate monthly and four (4\%) weekly.

Among the students who ingest alcoholic beverages, $11(23 \%)$ are fourth-year students and $37(77 \%)$ first-year students.

The parties and meetings take place at friends' houses $(44 \%)$; in pubs or restaurants $(33 \%)$, where alcoholic beverages are consumed; and they drink with friends or fellow students. The investigations show the reasons for ingesting alcoholic beverages: (35\%) answered that they drink for fun or pleasure.

Although the sample mostly consisted of firstyear students, these use larger amounts of alcohol than fourth-year students.

When the average age of the student groups who ingest alcoholic beverages with low risk (average of 27.09 years) is compared with that of students in the high-risk group (average of 23.33 years), younger students were found to use alcohol in highly risky amounts.

From this point, the differences between the weighed results and the level of risk in alcohol were studied, with no differences found. This justifies a study with a larger sample of students, including variables such as: missing classes, sleeping in classes, arriving late at classes due to a party the previous evening, and anticipation of use.

\section{DISCUSSION AND CONCLUSIONS}

This is the first time that alcohol consumption among nursing students in Honduras is evaluated. This study reveals the average consumption of alcoholic beverages in a sample of nursing students from the FCM.UNAH. 
According to the sample characteristics, most students are young people, mostly women who study and work, are married, and evangelic. Although the study sample is limited, these important traits will be explored in larger samples, since they are considered protection factors for the use of alcohol. Furthermore, many of these studies point to gender as a defining characteristic (men drink more than women), type of religion, (mainly evangelic, in which drinking is not allowed), having a spouse (people who live alone are more likely to consume alcoholic beverages), working and studying (which can also be considered as risk factors due to the overload of activities, which ends up generating stress and leading to the need to drink to relieve it. On the other hand, the students did not have much free time to drink). These considerations can affect the results of this study, but higher levels of abstinence were found in literature.

In this investigation of alcohol use, only one fourth of the sample was found to use alcoholic beverages. These rates are lower when compared to international studies ${ }^{(6-13)}$.

Regarding the places where students consume alcoholic beverages, it was found that friends' houses, pubs and restaurants are preferred. According to the author ${ }^{(15)}$, going to these places favors a more frequent consumption of alcohol.

The students drink with friends or classmates, and the ingestion of alcoholic beverages can work as a means of socialization, promoting encounters among young people and acceptance by the environment.

Literature clarifies (13-12) that the use of alcoholic beverages among university students happens in a recreational manner. But although $74.9 \%$ of abstinence was found in this study, the other 48 (25\%) students who do drink, at low risk and some type of risk, cannot be ignored, since they can increase this consumption over time ${ }^{(14)}$. National and international studies appoint rates of alcohol abuse among college students exceeding $60 \%$, which did not occur in this study.

There are some limitations to this study, such as false negative cases. Firstly, the use of alcohol is not always accepted by society, and is often considered a moral problem. Such data may have caused fear in these students, who are exposing their alcohol consumption to the public, and may later be identified as drinkers. Despite what previous orientations may say, this has not stopped students from answering the questions in the questionnaire truthfully.
This issue was observed in a number of students who answered affirmatively the question "drinks alcoholic beverages in parties" (56 students) when compared with the 48 who were pointed out in the AUDIT. A difference of about six students was found, which made the authors think of some possibilities for not answering.

Firstly, these young people received education and prevention about alcohol and drugs, an issue that generates a social stigma of little acceptance in professional health care. The theme is practically new and extremely relevant for nursing, since nurses are at the front line of care (intervention and prevention) delivery to patients with problems related to the use of this substance in several areas of healthcare and society.

Studies of this nature are very important to monitor the use of alcohol and drugs and to search for intervention and prevention strategies in college communities. In this sense, the Department of Nursing Education at FCM.UNAH aims to prepare professionals with high-quality scientific and technical knowledge in the drugs area. This institution considers it extremely important to objectively identify knowledge about students' use of alcoholic beverages, and has looked for the support of CICAD/OAS as a strategy to face this issue, with a view to designing and executing educational prevention and promotion programs at curriculum level in the nursing area, with themes related to the use of alcohol and drugs being offered at the institution and later in other nursing study centers throughout Honduras.

\section{ACKNOWLEDGEMENTS}

Acknowledgements to the Inter-American Drug Abuse Control Commission/CICAD of the SubSecretary of Multidimensional Security at the Organization of American States/OAS, the Brazilian Anti-Drugs Secretary/SENAD, faculty members at the University of São Paulo at Ribeirão Preto College of Nursing, WHO Collaborating Centre for Nursing Research Development, Brazil, to the population who participated in the studies and to the representatives from eight Latin-American countries who participated in the I and II On-Line Specialization Program for Research Capacity-Building on the Drugs Phenomenon-PREINVEST, offered in 2005/2006 by the University of São Paulo at Ribeirão Preto College of Nursing, as a distance education course. 


\section{REFERENCES}

1. Organización Mundial de la Salud (GN). Neurociencia del consumo y dependencia de sustancias psicoactivas Ginebra: Organización Mundial de la Salud; 2004.

2. Pyne HH, Claeson M, Correia M. Gender dimension of alcohol consumption and alcohol-related problems in Latin America and the Caribean. Washington, DC. International Bank for Reconstruction and Development/ The World Bank; 2002. (World Bank Discussion Paper n.433).

3. Instituto Hondureño para la Prevención del Alcoholismo, Drogadicción y Fármaco Dependencia (IHADEFA). Encuesta de Condiciones de vida [serial online] 2004. [Cited in 2006 oct 8]. Availabre from URL:http://www.unhchr.ch/tbs/doc.nsf 4. Midence ORS. Aspectos históricos y Psicossociales del alcoholismo en Honduras. Rev Med Hondur 1984; 52(3): 155-60.

5. Murra DE, Suazo GR, Alvarenga E. Consumo de drogas en Honduras. Rev Med Hond 2001 abril-jun; 69(2):75-9.

6. Peuker AC, Fogaça J, Bizarro L. Expectativas e beber problemático entre universitários. Piscol: Teoria e Pesquisa. 2006 mai-agost; 22(2):193-200.

7. Pillon SC, Webster-Corradi C.Teste de identificação de problemas relacionados ao uso de álcool entre estudantes universitários. Rev UERJ 2006 jul/set; 14(3):325-32.

8. Flores IEE, Luis MAV. Uso y actitudes relacionado a las estudiantes de enfermería de la Universidad Mayor de San Andrés. Rev Latino-am enfermagem 2004 março-abril; 13(n especial): 376-82.

9. Kokotailo PK, Egan J, Gangnon R, Brown D; Mundt M, Fleming M. Validity of the Alcohol Use Disorders Identification Test in college students. Alcohol Clin Exp Re 2004 jun; 28(6):914-20. 10. Pérez CL, Hernández WG, Valencia SC, Stefano L, Alpi V. Expectativas frente al consumo de alcohol en jóvenes universitarios colombianos. Anales de Psicologia 2005 diciembre; 21(2):259-67.

11. Araneda HJM, Repossi F, Puente A, Clemencia P. Qué, cuánto y cuándo bebe el estudiante universitario / What, how much and when does the university student drink? Rev. méd. Chile 1996 mar; 124(3):377-88.

12. Chavez KAP, O'Brien B, Pillon SC. Drugs use and risk behavior in a university community. Rev Latino-am Enfermagem 2005; 13( $\mathrm{n}$ especial):1194-200.

13. Pillon SC, O'Brien, B, Chavez KAP. The relationship between drugs use and risk behaviours in brasilian university. Revista Latino-am de Enfermagem 2005; 13(n especial): 1169-76.

14. Babor TF, Higgins-Biddle JC, Saunders JB, Monti PM, Monteiro MG. AUDIT The alcohol use disorders identification test: guidelines for use in primary care. Geneva: World Health Organization; 2001.

15. Kerr-Corrêa F, Simão MO, Dalben I, Trinca LA, Cerqueira ATAR, Mendes AA, et-al.. Possíveis fatores de risco para o uso de álcool e drogas entre estudantes universitários e colegiais da UNESP. J Bras Dep Quím 2002; 3(1):32-41. 